\title{
Relationship of circulating levels of 25(OH)D with parathyroid hormone in various stages of chronic kidney disease
}

\author{
Mojgan Jalalzadeh ${ }^{1,2^{*}}$, Seyed Nouraddin Mousavinasab ${ }^{3}$, Ali Rostami ${ }^{4}$ \\ ${ }^{1}$ Departmentof Nephrology, Loghman Hakim Hospital, Shahid-Beheshti University of Medical Sciences, Tehran, Iran \\ ${ }^{2}$ Metabolic Disorder Research Center, Zanjan University of Medical Sciences, Zanjan, Iran \\ ${ }^{3}$ Departmentof Biostatistics, Mazandaran University of Medical Sciences, Sari, Iran \\ ${ }^{4}$ Departmentof Nephrology, Modarres Hospital, Shahid-Beheshti University of Medical Sciences, Tehran, Iran
}

\section{A R T I C L E I N F O}

\section{Article Type:}

Original

\section{Article History:}

Received: 27 January 2017

Accepted: 20 May 2017

Published online: 4 June 2017

\section{Keywords:}

25-Hydroxy vitamin D

PTH

Chronic kidney disease

Hemodialysis

\begin{abstract}
A B S T RAC T
Introduction: Vitamin D deficiency is common in both general population and chronic kidney disease (CKD) patients.

Objectives: The aim of this study was to compare 25(OH)D3 levels in stages 2 to 5 of CKD patients and to evaluate whether inactive vitamin D supplement could prevent increasing of serum PTH levels.

Patients and Methods: A total of 58 stages 2-4 CKD and 57 stage 5 CKD hemodialysis (HD) patients who had $25(\mathrm{OH}) \mathrm{D} 3<30 \mathrm{ng} / \mathrm{mL}$ were considered. All cases were under appropriate treatment for preventing secondary hyperparathyroidism. At the beginning, serum levels of vitamin D3, intact parathyroid hormone (iPTH), calcium (Ca), phosphate (P), alkaline phosphate (ALP) and albumin were measured. Patients received 300000 IU/IM vitamin D3 and after 2 months this dosage was repeated, if it was necessary. All biochemical markers were checked and the effect of vitamin D3 was evaluated.

Results: At base line, serum levels of 25(OH)D3 and PTH in patients with stages 2 to 5 of CKD were; $14.85 \pm 7.8 \mathrm{ng} / \mathrm{mL}$ (stage 2), $70.8 \pm 16.8 \mathrm{pg} / \mathrm{mL}$ (stage 2); $16.48 \pm 7.8 \mathrm{ng} / \mathrm{mL}$ (stage 3), $69.6 \pm 39.2$ $\mathrm{pg} / \mathrm{mL}$ (stage 3); $16.33 \pm 8.1 \mathrm{ng} / \mathrm{mL}$ (stage 4), $123.74 \pm 92.5 \mathrm{pg} / \mathrm{mL}$ (stage 4); and $13.86 \pm 6.5 \mathrm{ng} / \mathrm{mL}$ (stage 5) and $567.23 \pm 276.7 \mathrm{pg} / \mathrm{mL}$ (stage 5), respectively.

Two months after injections, 25(OH)D3 and PTH were changed as follow; $28.62 \mathrm{ng} / \mathrm{mL}(P=0.001)$ (stage 2), $59.38 \mathrm{pg} / \mathrm{mL}(P=0.34)$ (stage 2$) ; 37.79 \mathrm{ng} / \mathrm{mL}(P<0.001)$ (stage 3$), 62.41 \mathrm{pg} / \mathrm{ml}(P=0.18)$ (stage 3); $31.14 \mathrm{ng} / \mathrm{mL}(P=0.001)$ (stage 4$), 91.02 \pm 69.4 \mathrm{pg} / \mathrm{mL}(P=0.003)$ (stage 4$)$ and $48.48 \mathrm{ng} / \mathrm{mL}$ $(P<0.001)$ (stage 5$)$ and also $282.77 \mathrm{pg} / \mathrm{mL}(P<0.001)$ (stage 5$)$, respectively.

Conclusion: The result of this study showed the vitamin D3 levels increased in all stages after 2 months. Also, the findings indicated that administration of vitamin D3 in all patients of the study groups reduced serum PTH levels. However, the rate of reduction was higher in stages 4 and 5 of CKD as compared to stages 2 and 3 of CKD $(P<0.001)$.This result encourages us to prescribe supplement vitamin D3 if the level is less than $30 \mathrm{ng} / \mathrm{mL}$.
\end{abstract}

\footnotetext{
Implication for health policy/practice/research/medical education:

In a study on 115 patients with stages 2 to $5 \mathrm{CKD}$ and the age of more than 14 years old, we found vitamin $\mathrm{D}$ deficiency as the serum level of $25(\mathrm{OH}) \mathrm{D} 3<30 \mathrm{ng} / \mathrm{mL}$, is common in CKD patients. There was a positive correlation between the serum levels of $25(\mathrm{OH}) \mathrm{D} 3$ and levels of PTH. The findings indicated that administration of vitamin D3 in all CKD patients with vitamin D deficiency was effective in reducing the serum levels of PTH.

Please cite this paper as: Jalalzadeh M, Mousavinasab SN, Rostami A. Relationship of circulating levels of 25(OH)D with parathyroid hormone in various stages of chronic kidney disease. J Renal Inj Prev. 2017;6(4):264-268. DOI: 10.15171/jrip.2017.50.
}

Introduction

Vitamin D absorbs from the diet or synthesis in derma from sunlight, but this product is biologically inactive and requires becoming active by hydroxylation in the liver and kidney (1). Active vitamin D stimulates absorption of calcium and phosphate from the intestine 
and kidney. It plays an important role in the mineral and bone homeostasis. Two essential pre-hormones are cholecalciferol $[25(\mathrm{OH}) \mathrm{D} 3]$ and ergocalciferol $[25(\mathrm{OH})$ D2].

A variety of causes develop vitamin D deficiency and insufficiency including low sun exposure, malabsorption, obesity, autoimmune disease and chronic kidney disease (CKD) (2).

A low serum level of vitamin $\mathrm{D}$ is associated with some disorders including multiple sclerosis, malignancy, cardiovascular disease and immune system dysfunction (3). Also, vitamin D deficiency is related to increase the risk of mortality in end-stage renal disease (ESRD) and in general population $(4,5)$.

Vitamin D has a significant role in the calcium and phosphorus homeostasis, suppression of parathyroid hormone, muscular balance and regulation of bone mineralization (5). Consequently, low levels of serum vitamin D develop elevation of serum PTH concentration in both healthy and CKD cases (6). Vitamin D deficiency is defined when $25(\mathrm{OH}) \mathrm{D} 3$ is less than $20-30 \mathrm{ng} / \mathrm{mL}$ (3). In 2009, vitamin D supplement was recommended for the kidney disease (7).

\section{Objectives}

The goal of this study was to compare the levels of 25(OH)D3 deficiencies in stages 2-5 CKD patients and to determine the effect of administration of vitamin D3 on serum PTH, calcium $(\mathrm{Ca})$, phosphorus $(\mathrm{P}), \mathrm{Ca} \times \mathrm{P}$ product, and alkaline phosphates (ALP).

\section{Patients and Methods}

This study was conducted in the nephrology outpatient clinic of Vali-e-Asr hospital of Zanjan University and three hemodialysis centers in Tehran. Duration of the study was four months. Different stages of CKD (stage 2: $\mathrm{GFR}=60-89 \mathrm{cc} / \mathrm{min}$; stage $3: \mathrm{GFR}=59-30 \mathrm{cc} / \mathrm{min}$; stage 4: $\mathrm{GFR}=15-29 \mathrm{cc} / \mathrm{min}$; and stage 5 , under $\mathrm{HD}, \mathrm{GFR}<15$ $\mathrm{cc} / \mathrm{min}$ ) have been considered. In addition, CKD patients diagnosed with vitamin $\mathrm{D}$ deficiency who were more than 14 years old with treatment of calcitriol and phosphate binder for at least 6 months were included. Patients with nephrotic syndrome, tertiary hyperparathyroidism, history of calcium kidney stone or excretion of calcium in 24 hours urine, and taking any medication that interfered with serum levels of vitamin D were excluded from the study. In this study, we considered a vitamin D deficiency when the serum level of 25(OH)D3 is less than $30 \mathrm{ng} / \mathrm{mL}$. We compared the measured level of $25(\mathrm{OH}) \mathrm{D} 3$ in the study groups and then evaluated and compared the injection effect of 25(OH) D3 on serum intact PTH (iPTH), Ca, P, $\mathrm{Ca} \times \mathrm{P}$ product, ALP. Fasting blood samples to assess of Ca, P, ALP, albumin, 25(OH) D3 and iPTH were obtained at base line, at after 2 months and at the end of the study, if it was necessary.

Serum of blood samples were tested for Ca by Arsenazo, $\mathrm{P}$ by photometric, ALP by photometric, albumin by Bromocresol Green, 25(OH) D3 by Acetonitile and iPTH level by immunoradiometric assay.

Patients were treated with calcium carbonate, renagel and calcitriol according to the level of $\mathrm{Ca}, \mathrm{P}$ and $\mathrm{PTH}$; the use of supplements continued during the study.

Patients received intramuscular shot of cholecalciferol (vitamin D3) 300000 units at the beginning and at the end of 2-month, if it was necessary. This re-administration was performed, if level of $25(\mathrm{OH}) \mathrm{D} 3$ still was less than $30 \mathrm{ng} / \mathrm{mL}$.

Over 2 and 4 months after treatment, the data was collected to assess the effects of vitamin D on Ca, P, Ca $\times \mathrm{P}$ product, ALP and iPTH.

Serum calcium concentration was corrected by serum albumin concentration and GFR was calculated according to the abbreviated the modification of diet in renal disease (MDRD) formula.

\section{Ethical issues}

1) The research followed the tenets of the Declaration of Helsinki; 2) informed consent was obtained; and 3) This study was approved by the Ethics Committee of Zanjan University of Medical Sciences (ethical code \# 90-514-01).

\section{Statistical analysis}

Statistical analysis was performed using SPSS for Windows (version 22) software. Data was created as mean \pm standard deviation (SD) for continuous variables and n (\%) for categorical variables. Chi-square test was used for comparisons of categorical variables. Additionally analysis of variance (ANOVA) test was used for normal variables. Mann-Whitney U, Wilcoxon signed-rank and Friedman tests were used for non-normal variables. Correlation analysis has been done with the use of Spearman's correlation measure. All of the statistical tests were two-sided. $P$ values of less than 0.05 were considered significant.

\section{Results}

In this study, 115 patients enrolled to the investigation (stage $2 ; 6$ patients, stage $3 ; 31$ patients, stage $4 ; 21$ patients and finally stage 5 under HD was 57 patients). Demographic information of patients has been shown in Table 1. The serum 25(OH) D3 levels in all subjects were low.

As presented in Table 1, at the base line, the mean of serum $25(\mathrm{OH}) \mathrm{D}$ in stages 2, 3, 4 and $5 \mathrm{CKD}$ under HD were $14.85 \pm 7.8 \mathrm{ng} / \mathrm{mL}, 16.48 \pm 7.8 \mathrm{ng} / \mathrm{mL}, 16.33 \pm 8.1 \mathrm{ng} / \mathrm{mL}$ and $13.86 \pm 6.5 \mathrm{ng} / \mathrm{mL}$, respectively $(P=0.33)$. Also, when serum levels of $25(\mathrm{OH}) \mathrm{D} 3$ were low, the amount of serum levels of iPTH were high for all stages CKD 2-5.

Spearman's correlation showed an inverse relationship between vitamin $\mathrm{D}$ and iPTH in base line $(r=-0.236$, $P=0.011$; Table 2).

After 2 months of vitamin D3 administration, Spearman's correlation coefficient showed a significant relation between PTH, 25(OH) D3 and other biochemical markers (Table 2).

The mean of body mass index (BMI) was found to be 
Jalalzadeh $\mathrm{M}$ et al

Table 1. Baseline characteristics of study population

\begin{tabular}{|c|c|c|c|c|c|}
\hline Variables & $\begin{array}{c}\text { Stage } 2 \\
\text { CKD }\end{array}$ & $\begin{array}{c}\text { Stage } 3 \\
\text { CKD }\end{array}$ & $\begin{array}{c}\text { Stage } 4 \\
\text { CKD }\end{array}$ & HD & $P$ value \\
\hline Gender (No. \%) & $\begin{array}{c}\mathrm{F}: 0(0 \%) \\
\mathrm{M}: 6(100 \%)\end{array}$ & $\begin{array}{l}F: 10(32.3 \%) \\
M: 21(67.7 \%)\end{array}$ & $\begin{array}{l}F: 14(66.7 \%) \\
M: 7(33.3 \%)\end{array}$ & $\begin{array}{c}\text { F: } 31(54.4 \%) \\
M: 26(45.6 \%)\end{array}$ & 0.006 \\
\hline Age (years) & $46.67 \pm 13.6$ & $53.11 \pm 18.2$ & $54.86 \pm 167.11$ & $55.28 \pm 12.9$ & 0.58 \\
\hline $\mathrm{BMI}\left(\mathrm{kg} / \mathrm{m}^{2}\right)$ & $23.21 \pm 3.3$ & $23.84 \pm 2.9$ & $24.77 \pm 2.3$ & $24.91 \pm 3.3$ & 0.58 \\
\hline $\mathrm{Ca}(\mathrm{mg} / \mathrm{dL})$ & $9.23 \pm 0.4$ & $9.33 \pm 0.4$ & $9.45 \pm 0.5$ & $9.10 \pm 0.5$ & 0.04 \\
\hline ALP (IU/L) & $191.0 \pm 84.3$ & $168.03 \pm 67.6$ & $189.76 \pm 70.3$ & $553.37 \pm 495.6$ & $<0.001^{*}$ \\
\hline$P(\mathrm{mg} / \mathrm{dL})$ & $3.63 \pm 0.5$ & $3.45 \pm 0.6$ & $4.08 \pm 0.7$ & $4.91 \pm 1.2$ & $<0.001^{*}$ \\
\hline $\operatorname{Ca} \times P\left(\mathrm{mg}^{2} / \mathrm{dL}^{2}\right)$ & $33.55 \pm 5.1$ & $32.3 \pm 5.9$ & $38.6 \pm 6.9$ & $44.47 \pm 10.1$ & $<0.001^{*}$ \\
\hline $\mathrm{Cr}(\mathrm{mg} / \mathrm{dL})$ & $1.43 \pm 0.4$ & $1.68 \pm 0.3$ & $2.57 \pm 0.4$ & $8.81 \pm 1.8$ & $<0.001^{*}$ \\
\hline BUN (mg/dL) & $36.00 \pm 9.8$ & $26.44 \pm 9.5$ & $46.04 \pm 14.7$ & $64.5 \pm 17.4$ & $<0.001^{*}$ \\
\hline iPTH (pg/mL) & $70.8 \pm 16.8$ & $69.6 \pm 39.2$ & $123.74 \pm 92.5$ & $567.23 \pm 276.7$ & $<0.001^{*}$ \\
\hline $25(\mathrm{OH}) \mathrm{D} 3(\mathrm{ng} / \mathrm{mL})$ & $14.85 \pm 7.8$ & $16.48 \pm 7.8$ & $16.33 \pm 8.1$ & $13.86 \pm 6.5$ & 0.33 \\
\hline Duration of dialysis (years) & - & - & - & $3.72 \pm 2.5$ & - \\
\hline
\end{tabular}

Abbreviations: CKD, chronic kidney disease; HD, hemodialysis; M, male; F, female; BMI, body mass index; iPTH, intact parathyroid hormone; Ca, calcium; P, phosphorus; ALP, alkaline phosphatase.

* Kruskal Wallis test.

Table 2. The Spearman's correlation between iPTH, vitamin D and other biochemical markers in base line and after two months of vitamin D3 administration

\begin{tabular}{|c|c|c|c|c|c|c|c|c|}
\hline & \multicolumn{2}{|c|}{$\begin{array}{l}\text { 25(OH)D3 }(\mathrm{ng} / \mathrm{mL}) \\
\text { Base line }\end{array}$} & \multicolumn{2}{|c|}{$\begin{array}{l}\text { iPTH }(\mathrm{pg} / \mathrm{mL}) \\
\text { Base line }\end{array}$} & \multicolumn{2}{|c|}{$\begin{array}{c}25(\mathrm{OH}) \mathrm{D} 3(\mathrm{ng} / \mathrm{mL}) \\
\text { After } 2 \text { months of vitD3 injection }\end{array}$} & \multicolumn{2}{|c|}{$\begin{array}{c}\text { iPTH }(\mathrm{pg} / \mathrm{mL}) \\
\text { After } 2 \text { months of vitD3 injection }\end{array}$} \\
\hline & $r$ & $P$ value & $r$ & $P$ value & $r$ & $P$ value & $r$ & $P$ value \\
\hline iPTH (pg/mL) & -0.236 & 0.011 & - & - & 0.191 & 0.04 & - & - \\
\hline Age (years) & -0.04 & 0.67 & -0.06 & 0.49 & -0.004 & 0.96 & -0.12 & 0.17 \\
\hline BMI $\left(\mathrm{kg} / \mathrm{m}^{2}\right)$ & 0.03 & 0.78 & 0.1 & 0.36 & -0.020 & 0.85 & 0.07 & 0.46 \\
\hline $\mathrm{Ca}(\mathrm{mg} / \mathrm{dL})$ & 0.15 & 0.1 & -0.359 & $<0.001$ & 0.11 & 0.25 & -0.429 & $<0.001$ \\
\hline$P(\mathrm{mg} / \mathrm{dL})$ & -0.04 & 0.6 & 0.566 & $<0.001$ & 0.18 & 0.04 & 0.468 & $<0.001$ \\
\hline $\operatorname{CaxP}\left(\mathrm{mg}^{2} / \mathrm{dL}^{2}\right)$ & -0.10 & 0.26 & -0.430 & $<0.001$ & 021 & 0.03 & 0.386 & $<0.001$ \\
\hline ALP (IU/L) & -0.12 & 0.22 & 0.70 & $<0.001$ & 0.27 & 0.04 & 0.37 & 0.005 \\
\hline Alb (g/dL) & 0.07 & 0.54 & -0.01 & 0.92 & 0.33 & 0.01 & 0.08 & 0.55 \\
\hline BUN (mg/dL) & -0.12 & 0.26 & 0.63 & $<0.001$ & 0.32 & $<0.001$ & 0.76 & $<0.001$ \\
\hline $\mathrm{Cr}(\mathrm{mg} / \mathrm{dL})$ & -0.17 & 0.06 & 0.80 & $<0.001$ & 0.27 & 0.01 & 0.66 & $<0.001$ \\
\hline
\end{tabular}

Abbreviations: BMI, body mass index; iPTH, intact parathyroid hormone; Ca, calcium; P, phosphorus; ALP, alkaline phosphatase; BUN, blood urea nitrogen; $\mathrm{Cr}$, creatine.

similar on all stages CKD. BMI had no significant effect on the serum 25(OH) D3 levels (Spearman's correlation $r=0.03, P=0.78$ ) of all patients in all groups. Furthermore, age did not show any correlation with the serum $25(\mathrm{OH})$ D3 levels (Spearman's correlation; $r=-0.04, P=0.6$ ) (Table 2).

Females with stages 2-4 CKD had more vitamin D3 deficiency than male significantly $(19.8 \pm 7$ vs. $13.7 \pm 7 \mathrm{ng} /$ $\mathrm{mL}, P=0.005)$.

Two months after injection of cholecalciferol (300000 IU/IM vitamin D3), a significant elevation of $25(\mathrm{OH})$ D3 concentration from baseline was detected as follows: stage 2 from $14.85 \mathrm{ng} / \mathrm{mL}$ (95\% CI, 8.6-21.2) to $28.62 \mathrm{ng} /$ $\mathrm{mL}$ (95\% CI, 23.6-33.8), $P=0.001$; stage 3 from $16.48 \mathrm{ng} /$ $\mathrm{mL}(95 \% \mathrm{CI}, 13.7-19.2)$ to $37.79 \mathrm{ng} / \mathrm{mL}$ (95\% CI, 32.343.1), $P<0.001$; stage 4 from $16.33 \mathrm{ng} / \mathrm{mL}$ (95\% CI, 12.8 -19.8 ) to $31.14 \mathrm{ng} / \mathrm{mL}$ (95\% CI, 24.5-37.7), $P=0.001$ and finally stage 5 (HD) patients from $13.85 \mathrm{ng} / \mathrm{mL}$ (95\% CI, $12.2-15.5)$ to $48.48 \mathrm{ng} / \mathrm{mL}$ (95\% CI, 43.1-53.9), $P<0.001$ (Table 3).

In addition, 2 months after injection of cholecalciferol, serum iPTH level of participants reduced as follow: stage $2(70.85 \pm 16.8$ to $59.38 \pm 25.4 \mathrm{pg} / \mathrm{mL}, P=0.34)$; stage $3(69.67 \pm 39.2$ to $62.41 \pm 29.1 \mathrm{pg} / \mathrm{ml}, P=0.18)$; stage 4 (123.74 \pm 92.5 to $91.02 \pm 69.4 \mathrm{pg} / \mathrm{mL}, \quad P=0.003$ ); and finally HD patients $(567.22 \pm 276.7$ to $282.77 \pm 183.65 \mathrm{pg} /$ $\mathrm{mL}, \quad P<0.001)$.

A significant relationship between iPTH and levels of $25(\mathrm{OH}) \mathrm{D} 3$ has been shown at stages 4 and $5 \mathrm{CKD}$ patients (Table 3).

Accordingly, no significant change of serum of Ca or P after treatment was detected. However significant increases was observed in $\mathrm{Ca} \times \mathrm{P}$ product in stage 3 ( $P=0.029$; Table 3 ).

Out of 115 cases included in the study, the levels of $25(\mathrm{OH}) \mathrm{D} 3$ reached to more than $30 \mathrm{ng} / \mathrm{mL}$ after first injection of vitamin D3 in 85 patients. Around 25 persons received second injection in second month, which caused the level of $25(\mathrm{OH}) \mathrm{D} 3$ reaches to more than $30 \mathrm{ng} / \mathrm{mL}$ in 20 of them. However, the amount of vitamin remained less than $30 \mathrm{ng} / \mathrm{mL}$ in five remaining cases. Additionally five participants did not pursue the study (Table 4).

The results show the efficacy of injected vitamin D3 after 
Table 3. Comparison of different variables between the groups, 2 and 4 months after vitamin D3 therapy

\begin{tabular}{|c|c|c|c|c|c|c|c|c|c|c|}
\hline Variables & $\begin{array}{l}\text { 25(OH)D } \\
\text { (ng/mL) }\end{array}$ & $P$ value & $\begin{array}{c}\text { iPTH } \\
\text { (pg/mL) }\end{array}$ & $P$ value & $\begin{array}{c}\mathrm{Ca} \\
(\mathrm{mg} / \mathrm{dL})\end{array}$ & $P$ value & $\begin{array}{c}P \\
(\mathrm{mg} / \mathrm{dL})\end{array}$ & $\begin{array}{c}P \\
\text { value }\end{array}$ & $\begin{array}{c}\text { CaxP product } \\
\left(\mathrm{mg}^{2} / \mathrm{dL}^{2}\right)\end{array}$ & $P$ value \\
\hline \multicolumn{11}{|l|}{ Stage 2} \\
\hline Baseline & $14.85 \pm 7.8$ & \multirow{3}{*}{$0.04^{b}$} & $70.85 \pm 16.8$ & \multirow{3}{*}{$0.36^{b}$} & $9.23 \pm 0.4$ & \multirow{3}{*}{$0.71^{\mathrm{b}}$} & $3.63 \pm 0.5$ & \multirow{3}{*}{$0.83^{b}$} & $33.54 \pm 5.1$ & \multirow{3}{*}{0.72} \\
\hline After 2 months & $28.62 \pm 6.4$ & & $59.38 \pm 25.4$ & & $9.42 \pm 0.4$ & & $3.65 \pm 0.6$ & & $33.22 \pm 4.9$ & \\
\hline After 4 months & $45.83 \pm 11.8$ & & $47.41 \pm 35.5$ & & $9.30 \pm 0.5$ & & $3.84 \pm 0.2$ & & $35.67 \pm 0.3$ & \\
\hline \multicolumn{11}{|l|}{ Stage 3} \\
\hline Baseline & $16.48 \pm 7.8$ & \multirow{3}{*}{$<0.001^{b}$} & $69.67 \pm 39.2$ & \multirow{3}{*}{$0.86^{b}$} & $9.33 \pm 0.5$ & \multirow{3}{*}{$0.44^{b}$} & $3.45 \pm 0.6$ & \multirow{3}{*}{$0.09^{b}$} & $32.28 \pm 5.9$ & \multirow{3}{*}{0.029} \\
\hline After 2 months & $37.79 \pm 15.4$ & & $62.41 \pm 29.1$ & & $9.35 \pm 0.6$ & & $3.65 \pm 0.6$ & & $34.36 \pm 6.5$ & \\
\hline After 4 months & $38.97 \pm 8.8$ & & $88.22 \pm 61.4$ & & $9.61 \pm 0.5$ & & $3.79 \pm 0.6$ & & $36.64 \pm 7.3$ & \\
\hline \multicolumn{11}{|l|}{ Stage 4} \\
\hline Baseline & $16.33 \pm 8.1$ & \multirow{3}{*}{$0.007^{b}$} & $123.74 \pm 92.5$ & \multirow{3}{*}{$0.076^{\mathrm{b}}$} & $9.4 \pm 0.5$ & \multirow{3}{*}{$0.40^{\mathrm{b}}$} & $4.08 \pm 0.7$ & \multirow{3}{*}{$0.38^{b}$} & $38.64 \pm 6.9$ & \multirow{3}{*}{0.49} \\
\hline After 2 months & $31.14 \pm 15.1$ & & $91.02 \pm 69.4$ & & $9.6 \pm 0.7$ & & $3.9 \pm 0.8$ & & $37.38 \pm 10.1$ & \\
\hline After 4 months & $37.69 \pm 15.7$ & & $91.35 \pm 56.48$ & & $9.22 \pm 0.5$ & & $4.08 \pm 0.5$ & & $37.49 \pm 5.4$ & \\
\hline \multicolumn{11}{|l|}{ Stage 5 (HD) } \\
\hline Baseline & $13.85 \pm 6.5$ & \multirow{2}{*}{$<0.001^{\mathrm{a}}$} & $567.23 \pm 276.7$ & \multirow{2}{*}{$<0.001^{\mathrm{a}}$} & $9.1 \pm 0.5$ & \multirow{2}{*}{$0.005^{\mathrm{a}}$} & $4.91 \pm 1.1$ & \multirow{2}{*}{$0.10^{\mathrm{a}}$} & $44.61 \pm 10.1$ & \multirow{2}{*}{0.81} \\
\hline After 2 months & $48.48 \pm 20.7$ & & $282.77 \pm 183.6$ & & $8.7 \pm 0.7$ & & $5.21 \pm 1.3$ & & $45.21 \pm 10.6$ & \\
\hline
\end{tabular}

ailcoxon sign ranks test; ${ }^{\mathrm{b}}$ Friedman test.

Table 4. Effect of injected vitamin D3 on stages 2-5 CKD cases

\begin{tabular}{|c|c|c|c|c|c|}
\hline Variables & $\begin{array}{c}\text { Stage } 2 \\
\text { CKD }(n=6)\end{array}$ & $\begin{array}{c}\text { Stage } 3 \\
\text { CKD }(n=31)\end{array}$ & $\begin{array}{c}\text { Stage } 4 \\
\text { CKD }(n=21)\end{array}$ & $\begin{array}{c}\text { Stage } 5 \\
\text { (HD) }(n=57)\end{array}$ & Total $(n=115)$ \\
\hline $25(\mathrm{OH}) \mathrm{D} \geq 30$ (ng/mL) (after 2 months) & $3(50 \%)$ & $20(64.5 \%)$ & $11(52.4 \%)$ & $51(89.5 \%)$ & $85(73.9 \%)$ \\
\hline $25(\mathrm{OH}) \mathrm{D} \geq 30$ (ng/mL) (after 4 months) & $3(50 \%)$ & $10(32.2 \%)$ & $7(33.3 \%)$ & $0(0 \%)$ & 20 \\
\hline $25(\mathrm{OH}) \mathrm{D}<30$ (ng/mL) (after 4 months) & $0(0 \%)$ & 1 & $3(14.3 \%)$ & $1(1.7 \%)$ & 5 \\
\hline Not follow & $0(0 \%)$ & 0 & $0(0 \%)$ & $5(8.8 \%)$ & 5 \\
\hline
\end{tabular}

2 months was higher in stages 3 and 5 than stages 2 and 4 CKD $(P=0.003)$.

\section{Discussion}

Low level of 25(OH)D3 has been reported in the normal populations and CKD patients (8).

Low level of vitamin D3 is associated with osteoporosis, rickets, cardiovascular disorder, some autoimmune disease, multiple sclerosis, diabetes mellitus and some cancers (9). It has been suggested that low level of vitamin $\mathrm{D}$ decreases the survival of general population and CKD and HD patients $(10,11)$.

Recent observations showed a positive relation between level of $25(\mathrm{OH}) \mathrm{D}$ and $1.25(\mathrm{OH}) 2 \mathrm{D}$ in CKD patients $(8,12,13)$.

Vitamin D can suppress PTH production in the parathyroid glands (3). As a result, low serum level of vitamin D inversely increases serum PTH concentration in healthy and CKD patients (14).

In our study, we compared vitamin D3 deficiency in different stages of CKD. Then at the base line we evaluated the relations between the serum level of vitamin D3 with blood level of PTH, Ca, P, ALP and CA $\times$ P product; then effect of administration of vitamin D3 on these biochemical markers was investigated.

Melamed and Thadhani reported that there is an association between stage of CKD and vitamin D deficiency (11). This association is probably related to poor appetite, protein restriction, activity loss and less exposure to sunlight (11).

Many studies have shown 25(OH) D values are less than $30 \mathrm{ng} / \mathrm{mL}$ in patients with CKD and $\operatorname{ESRD}(13,15,16)$. Other investigators have found a positive association between low level of 25(OH) D and PTH levels in CKD cases $(17,18)$.

In our study, the lowest mean level of vitamin $\mathrm{D}$ was measured in stage 2 and 5 CKD patients. In HD patients, the lowest level of vitamin D3 was probably attributed to their low activity and not exposure to the sun; since the number of patients on stage 2 was low, we could not rely on this accidental finding.

Based on a previous study (19) and our findings, there is an association between serum level of $25(\mathrm{OH}) \mathrm{D} 3$ and PTH levels at all stages of CKD; this connection was more obvious in stage 5 CKD patients.

It is suggested that, if hyperparathyroidism is detected in CKD patients with vitamin D deficiency, this abnormality should be corrected with hyperparathyroidism control (8). Researchers have shown that increasing serum 25(OH) $\mathrm{D}$ concentrations by administration of cholecalciferol can reduce serum PTH levels (20-23). However, Kovesdy et al believes inactive vitamin D cannot reduce PTH levels (24). In our study, injecting vitamin D3 (300 000 IU/IM) after 2 months significantly decreased serum PTH levels at stages 4 and 5 CKD. 


\section{Conclusion}

Vitamin D3 supplement is needed in CKD patients. Further studies are required to clarify the optimal time to screen vitamin D deficiency, efficiency of vitamin D3 to control hyperparathyroidism and outcome of inactive vitamin D3 therapy.

\section{Limitations of the study}

There was a risk of vascular calcification and hypercalcemia due to vitamin D supplement. So we used it with caution during treatment.

\section{Authors' contribution}

MJ conceived the study and MJ and AR performed the experiments. SNM analyzed the data. MJ drafted the final manuscript; all authors read, revised and approved the final manuscript.

\section{Conflicts of interest}

The authors declare no conflict of interest.

\section{Ethical considerations}

Ethical issues (including plagiarism, data fabrication, double publication) have been completely observed by the authors.

\section{Acknowledgments}

The authors would like to thank Metabolic Disorder Research Center of Zanjan, Iran

\section{Funding/ Support}

The study was approved by ethics committee of Zanjan University of Medical Sciences (ethical code\# 90-514-01).

\section{References}

1. Sadlier D, Magee C. Prevalence of $25(\mathrm{OH})$ vitamin D (calcidiol) deficiency at time of renal transplantation: a prospective study. Clin Transplant. 2007;21:683-8. doi: 10.1111/j.13990012.2007.00696.

2. Zittermann A. Vitamin $\mathrm{D}$ in preventive medicine: are we ignoring the evidence? Br J Nutr. 2003;89:552-72. doi: 10.1079/ BJN2003837.

3. Holick MF. Vitamin D deficiency. N Engl J Med. 2007;357:26681. doi: $10.1056 /$ NEJMra070553.

4. Kuroda T, Shiraki M, Tanaka S, Ohta H. Contributions of 25-hydroxyvitamin D, co-morbidities and bone mass to mortality in Japanese postmenopausal women. Bone. 2009;44:168-72. doi: 10.1016/j.bone.2008.03.023.

5. Matias PJ, Ferreira C, Jorge C, Borges M, Aires I, Amaral $\mathrm{T}$, et al. 25-Hydroxyvitamin D3, arterial calcifications and cardiovascular risk markers in haemodialysis patients. Nephrol Dial Transplant. 2009;24:611-8. doi: 10.1093/ndt/gfn502.

6. Ritter C, Armbrecht H, Slatopolsky E, Brown A. 25-Hydroxyvitamin D3 suppresses PTH synthesis and secretion by bovine parathyroid cells. Kidney Int. 2006;70:6549. doi: 10.1038/sj.ki.5000394.

7. Group KDIGOC-MW. KDIGO clinical practice guideline for the diagnosis, evaluation, prevention, and treatment of Chronic Kidney Disease-Mineral and Bone Disorder (CKD-MBD). Kidney Int Suppl. 2009:S1-130. doi: 10.1038/ki.2009.188.

8. Al-Badr W, Martin KJ. Vitamin D and kidney disease. Clin J Am Soc Nephrol. 2008;3:1555-60. doi: 10.2215/CJN.01150308.

9. Zhang R, Naughton DP. Vitamin D in health and disease: current perspectives. Nutr J. 2010; 9:1. doi: 10.1186/1475-28919-65.

10. Gal-Moscovici A, Sprague SM. Use of vitamin D in chronic kidney disease patients. Kidney Int. 2010;78:146-51. doi: 10.1038/ki.2010.113.

11. Melamed ML, Thadhani RI. Vitamin D therapy in chronic kidney disease and end stage renal disease. Clin J Am Soc Nephrol. 2012;7:358-65. doi: 10.2215/CJN.04040411.

12. LaClair RE, Hellman RN, Karp SL, Kraus M, Ofner S, Li Q, et al. Prevalence of calcidiol deficiency in CKD: a cross-sectional study across latitudes in the United States. Am J Kidney Dis. 2005;45:1026-33.

13. González EA, Sachdeva A, Oliver DA, Martin KJ. Vitamin D insufficiency and deficiency in chronic kidney disease. Am J Nephrol. 2004;24:503-10. doi:10.1159/000081023.

14. Mehrotra R, Kermah D, Budoff M, Salusky IB, Mao SS, Gao YL, et al. Hypovitaminosis D in chronic kidney disease. Clin J Am Soc Nephrol. 2008;3:1144-51. doi: 10.2215/CJN.05781207.

15. Wolf M, Shah A, Gutierrez O, Ankers E, Monroy M, Tamez $\mathrm{H}$, et al. Vitamin D levels and early mortality among incident hemodialysis patients. Kidney Int. 2007;72:1004-13.

16. Bhan I, Burnett-Bowie SA, Ye J, Tonelli M, Thadhani R. Clinical measures identify vitamin D deficiency in dialysis. Clin J Am Soc Nephrol. 2010;5:460-7. doi: 10.2215/CJN.06440909.

17. Sliem H, Tawfik G, Moustafa F, Zaki H. Relationship of associated secondary hyperparathyroidism to serum fibroblast growth factor-23 in end stage renal disease: A case-control study. Indian J Endocrinol Metab. 2011;15:105.

18. Thacher TD, Clarke BL. Vitamin D insufficiency. Mayo Clin Proc. 2011;86:50-60.

19. Jalalzadeh M, Mousavinasab N. Effects of inactive vitamin D on persistent secondary hyperparathyroidism in patients on hemodialysis.Nephrourol Mon. 2017;9:e45029.

20. Chandra P, Binongo J, Ziegler T, Schlanger L, Wang W, Someren J, et al. Cholecalciferol (vitamin D3) therapy and vitamin $\mathrm{D}$ insufficiency in patients with chronic kidney disease: a randomized controlled pilot study. Endocr Pract. 2008;14:10-7.

21. Dogan E, Erkoc R, Sayarlioglu H, Soyoral Y, Dulger H. Effect of depot oral cholecalciferol treatment on secondary hyperparathyroidism in stage 3 and stage 4 chronic kidney diseases patients. Ren Fail. 2008;30:407-10.

22. Oksa A, Spustová V, Krivosíková Z, Gazdíková K, Fedelesová $\mathrm{V}$, Lajdová I, et al. Effects of long-term cholecalciferol supplementation on mineral metabolism and calciotropic hormones in chronic kidney disease. Kidney Blood Press Res. 2008;31:322.

23. Kandula P, Dobre M, Schold JD, Schreiber MJ, Mehrotra R, Navaneethan SD. Vitamin D supplementation in chronic kidney disease: a systematic review and meta-analysis of observational studies and randomized controlled trials. Clin J Am Soc Nephrol. 2011;6:50-62.

24. Kovesdy CP, Lu JL, Malakauskas SM, Andress DL, KalantarZadeh K, Ahmadzadeh S. Paricalcitol versus ergocalciferol for secondary hyperparathyroidism in CKD stages 3 and 4 : a randomized controlled trial. Am J Kidney Dis. 2012;59:58-66.

Copyright $\odot 2017$ The Author(s); Published by Nickan Research Institute. This is an open-access article distributed under the terms of the Creative Commons Attribution License (http://creativecommons.org/licenses/by/4.0), which permits unrestricted use, distribution, and reproduction in any medium, provided the original work is properly cited. 